\title{
疼痛治療法の変遷
}

日本良導絡自律神経学会 会長

日本大学名誉教授

鈴 木 太*

疼痛治療法は近年著しく進歩した。その理 由は従来研究の遅れていた痛みの分野での基 礎研究に力が注がれるようになったこと、お よびその成果が急速に臨床に取り入れられた ことによる。本稿では疼痛治療法を飛躍的に 進歩させた画期的な出来事をまず紹介し、合 せて主な疾患に用いられてきた治療法につい て考察する。

\section{A. 疼痛治療法進歩の画期的出来事}

1. Bonica, J.J.: The Management of Pain 発刊 (1953) (1)

「痛み」を真正面から取り上げ、これへの 対処法が1,500 ページにわたって述べられた 画期的な本であり、多くの医師、ことに麻酔 科の医師達に強烈な刺激を与えた名著であ る。本書には「With Special Emphasis on the Use of Analgesic Block in Diagnosis, Prognosis, and Therapy」という副題がつい ている。これからも明らかなように、本書は 神経ブロックが痛みを伴う疾患の診断と治療 に重要な役割を持っていることを強調し、そ の後のペインクリニック及び神経ブロック療 法発展の引き金となった。

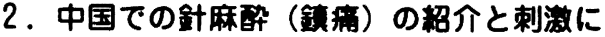 よる䤠捅法の発展（1971）}

脳や脊䯣を電気刺激して無痛を得ようとす る研究はすでに20世紀初頭から実験的に行わ れていた。しかし臨床例で身体の末梢に機械 的あるいは電気的刺激を加えただけで手術が
可能な程度の鎮痛が得られることが中国から 報告され、センセーションを巻き起こした。 これを契機に実験的、臨床的に研究が進んだ 結果、この方法は全感覚や運動の麻痷を伴う 「麻酔」とは異なり、痛覚のみを遮断あるい は抑制する「鎮痛法」であること、動物での 中脳水道周囲灰白質刺激により得られる鎮痛 と近似であること、内因性鎮痛物質が関与し ていること、固体により効果に差のあること 等が明らかになった。このような性質から、 この方法は手術の麻酔法としては欠点が多い が、鎮痛法の一つとして利用価値の高いこと が認められている(2)。更にこれらの研究を契 機として、刺激による鎮痛法全体が改めて見 直され、この分野での研究が急速に進歩した。 現在では末梢での刺激法以外に、硬膜外での 脊髄刺激、脳深部刺激、脳運動野刺激などが 一部の難治性疼痛疾患の治療に応用されてい る。

これらの出来事は更に多くの研究者に中枢 神経内での痛み刺激の伝達や伝達物質、種々 の内因性鎮痛物質等に関する研究意欲を刺激 したことも特筆すべき事項であろう。

3. Yaksh, T.L. 等 : 背稙でのオピオイド受 容体の証明 (1976) (3)

Yaksh 等はラットの脊椎くも膜下に細管 を挿入する技法を開発、これを通じて種々の 薬剤の脊㕼に対する直接作用を研究した。そ の結果、脊䯣にオピオイドが直接作用して高 度の鎮痛を起こすことを発見し、脊䯣にオピ

\footnotetext{
*駿河台日本大学病院麻醉科 $\overline{\mathrm{T}} 101-8309$ 東京都千代田区神田駿河台1-8-13 TEL $\cdot$ FAX 03-3391-7319

キーワード：ペインクリニック、疼痛治療法
} 
オイド受容体が存在することを明らかにし た。

この報告は基礎の研究者は勿論、臨床医に も重大な情報として受け取られ、わずか 2 年 後、くも膜下あるいは硬膜外から脊㖪一のモ ルヒネ投与による鎮痛法として登場した。こ の方法は全身投与よりも遥かに少量のモルヒ ネで優れた鎮痛効果が得られること、痛覚以 外の感覚や運動は正常に保たれること、モル ヒネ以外のオピオイドでも同様の鎮痛が得ら れることから、ことにそれまで良い方法の無 かった手術後の鎮痛法として優れた効果を発 揮することになった。現在手術後を始めとし て、数日から 1 週間程度の急性痛の治療法と して第一選択される方法になっている。

更にYaksh等はこの実験法を用いて沢山 の物質の脊䯣に対する作用、また脊㖪の細胞 から放出される種々の刺激伝達物質を明らか にし、疼痛研究に大きな功績を残した。

4.「WHO 方式瘦疼痛治瘦法」の発表 (1986) (4)

著者が駿河台日本大学病院で行った疼痛治 療患者第 1 号は1963年 6 月、胃癌の腹腔内転 位による腹痛で、内蔵神経ブロックで対処し た。当時このように癌による痛みに対応する 治療を行う施設は極めて限られており、多く の患者は癌末期痛で苦しみながら最後を迎え ていた。対応する治療法としては、我慢が出 来ない程の痛みにせいぜいモルヒネ $10 \mathrm{mg}$ 皮下注射する程度であった。

この状態を改善すべく、WHO では特別な 技術や設備がなくても施行できる鎮痛薬の内 服を $2 つ の$ 原則のもとに用い、癌の痛みから 患者を解放するための指針を発表した。原則 の第 1 は服用した鎮痛薬の薬理学的効果が持 続している間に次の服薬をさせる、すなわち 薬剤の効果持続時間に従って「時刻を決めて 规則正しく（by the clock）投与すること、 第 2 は鎮痛薬を(1)麻薬でない鎮痛薬、(2)弱い 麻薬、(3)強い麻薬の 3 つの群に分け、「抗力 の強さに従って段階的に (by the ladder)薬 を選ぶこと」である。また薬剤の量も鎮痛が 得られるまで十分な量を服薬させることも指
摘された。

この指針の普及により、現在はかなりの患 者が痛みから解放されるようになったが、未 だ十分に活用されているとは言えない。

\section{PCA を始めとした薬剤の投与方法の多様} 化 (1990年代)

痛みの基礎研究が進むに従い、痛み刺激が 持続的に脊㖪へ入力されると、脊噵後角の侵 害受容ニューロンが感作され、後から入力さ れる侵害刺激に対して過敏となることが証明 されるようになった。臨床的には痛みを我慢 させてから鎮痛薬を用いると、最初から痛み を抑制できる量の鎮痛薬を用いた場合よりも 多くの量の鎮痛薬を必要とする。このような 事実から、患者が痛みを感じたら自分でボ夕 ン操作をすることにより、決められた薬剤が 注入される装置の開発が進み、Patient Controlled Analgesia (PCA)装置として普及 するようになった。

また内服薬でも 1 日 1 回の服用で24時間効 果の持続する徐放剂、皮膚から吸収させる貼 付剂、粘膜から吸収させる噴霧剤等開発が進 んでいる。

6. Woolf, C.J. : Preemptive Analgesia の

提唱（1991）(5.6)

上述したように侵害刺激の持続的入力が脊 娟道後角の侵害受容ニューロンの感作を引き起 こすことが明らかとなった。そこで手術に伴 う痛みのように予め侵害刺激の発生が予測で きる場合、その前から刺激の受容を遮断ある いは抑制しておけば、侵害受容ニューロンの 感作を防止でき、術後の痛みを抑制し、鎮痛 薬の使用量も減少するであろうという理論で ある。すなわち現在では全身麻酔での手術で も前投薬から十分な鎮痛薬を用いたり、神経 ブロックを併用して術野からの侵害刺激を遮 断する方法が推賞され、実施されている。

\section{B. 主な疾患に用いられてきた治療法}

\section{1. 特発性三叉神経痛}

強烈な顔面痛だけを主徴とする典型的な疼 痛疾患である。本症に対してはJannetta， P.G. ${ }^{(7)}$ による脳神経血管隇圧術の開発以来、 
その病態に対する考えかたが多いに変化し た。しかしこの方法のみで総べての症例に対 処可能というわけではない。種々の条件によ り手術の適応とならない例や再発例の問題が ある。過去から現在まで次に挙げるような治 療法が試みられ、それぞれある程度の効果を あげてきた。しかしいずれの方法もその方法 特有の欠点もまた持っている。現状では抗痙 攀薬が先ず用いられ、それに加えて施設によ り得意とする方法が選択され、それで対処出 来ない症例は別の方法が採られている。

a. 抗痤摮薬（カルバマゼピン、その他）

b. 神経ブロック療法（局所麻酔薬、神経 破壊薬)

c. 三叉神経節高周波熱凝固法

d . 三叉神経槽内グリセロール注入法

e. 脳神経血管减圧術

f ．ガンマナイフによる方法

\section{2.癌による痛み}

著者の在職した駿河台日本大学病院では 1963年以来 2000 年までに約 1000 例の癌性疼痛 患者の治療を行ってきた。従ってその経過を 振り返ってみることは、即癌性疼痛治療法の 変遷をみることになる。そこで伊藤真介等(8) がこの1000例の経過を分析した結果の要点を 次に示す。

a . 症例数

5 年毎に区切って比較してみると、1990年 からの 5 年間が最も症例数が多かった。1995 年以降に症例数が減少傾向にあるのは、 WHO方式 (4) が普及し、軽度の疼痛に対し ては各科である程度対応が可能になったため と思われる。

b. ペインクリニック受診以前の疼痛治療 1979年までの症例では約70\%の例が何も処 置されていなかった。最近ではそれが20\%以 下に隇少している。1979年までに予め処置さ れていた症例でもその内容は消炎鎮痛薬かぺ ンタゾシンの単回投与が殆どであった。最近 ではWHO方式による治療が40\%近くの例に 採られており、それでも鎮痛できない例がペ インクリニックに紹介されてくる。

$$
\text { c . ペインクリニックでの治療法 }
$$

1985年までは全症例のほほ50\%は内臓神経 ブロック、あるいはくも膜下フェノールブロ ックで対処されていた。さらにこれらブロッ クで処置できない例の $20-30 \%$ は持続硬膜外 ブロックが用いられていた。1987年以降 WHO方式に従った治療方式が導入されると これが主流となり、現在では殆どの症例がこ の方式で治療され、ごく一部の例に神経ブロ ックが用いられているのみとなった。

\section{d. 転帰}

上記のように治療方針が大変化した結果は どうか。1985年以前では神経ブロックが成功 し、鎮痛が得られると以後の追跡がされてい ない例がほほ40\%存在した。これに対して最 近では鎮痛治療が続けられたまま死亡まで追 跡された例が $60 \%$ 以上、鎮痛を得て投薬を続 けたまま退院あるいは転院した例が20\%を占 めている。反面神経ブロックは適応が正しく 行われると、良質な鎮痛の得られることも明 らかとなり、これらの結果と各例での経過の 分析から、最近でば治療法がWHO方式に片 寄り過ぎ、神経ブロックの機会を逸してしま った例があることを率直に反省している。

\section{3. 帯状疮疹後神経痛に対する治療法}

帯状疮疹後神経痛を始めとする神経因性疼 痛（Neuropathic Pain）は現在鎮痛に最も困 難を感ずる病態である。一口で言えば、現在 これを完全に治瘉せしめる方法はなく、痛み を紸和させ得る幾つかの方法を組み合わせ、 患者の訴える痛みをせめて半隇できれば可と する程度が現状である。

本症に対しては過去 1 世紀に亘って実にい ろいろな方法が試みられ、無効あるいはむし ろ悪化という結果から捨てられてきた。例え ば、各種のビタミン剤やステロイド剤、神経 破壊薬による神経ブロック、種々な部位での 神経切断や切除術等である。

現在では本症による痛みを楥和する作用を 持つことが知られている次の方法を組み合わ せて対処している。 


\section{a. 内服薬}

抗輥薬（アミトリプチリン、その他）、抗

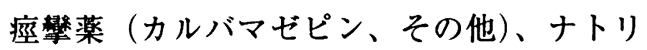
ウムチャンネル遮断薬（メキシレチン、その 他)、ノイロトロピン等

b. 神経ブロック

局所麻酔薬による交感神経あるいは羅患神 経ブロックをくり返す。

c . 刺激による鎮痛法

前述した各種の刺激法が有効な例がある。

d. 䍜患部局所に用いる方法

(1) 局所麻酔薬の浸潤

（2）イオントフォレーシス（局所麻酔薬あ るいはステロイド)

（3）低出カレーザーや遠赤外線照射

（4）冷凍あるいは凝固

（5）局所麻酔薬や鎮痛薬のフイルム貼付

(6) カプサイシンクリーム（開発中）

以上述べたように、痛みの治療法の進歩は 基礎研究と密接に結びついて始めて可能であ る。過去がそうであったじ、これからもそう であろう。ただ基礎研究の結果を臨床に応用 するに当たっては常に安全性についての十分 な確認の下で行われなくてはならない。

\section{文 献}

(1) Bonica, J.J: The Management of Pain, With Special Emphasis on the Use of Analgesic Block in Diagnosis, Prognosis, and Therapy, Iea \& Febiger, Philadelphia, 1953

（2）宮崎東洋、他：特集「末梢刺激による鎮痛療 法一使用方法および適応と限界」、ペインクリ ニック、21：171-211、2000

(3) Yaksh, T.L., et al:Analgesia mediated by a direct spinal action of narcotics, Science, 192: 1357-8, 1976

（4）世界保健機関編、武田文和訳：がんの痛みか らの解放、付. WHO 方式癌疼痛治療法、金 原出版、東京、昭和 62 年

(5) Woolf,C.J. Evidence for a central component of post-injury pain hypersensitivity, Nature, 306: 686-8.1983

(6) Woolf, C.J., et al: The induction and maintenance of central sensitization is dependent on N-methyl-D-aspartic acid receptor activation; implications for the treatment of post-injury pain hypersensitivity states, Pain, 44: 293-9, 1991

(7) Jannetta,P.J:Trigeminal neuralgia:Treatment by microvascular decompression. In Neurosurgery. Vol 3.Ed by R.H. Wilkins and S.S. Rengachary,New York, McGraw Hill Book, 1985, 2357-2363

（8）伊藤真介、他：癌性疼痛憈和治療1000例、日 本ペインクリニック学会第 34 回大会、東京、 2000 年 7 月 14 日 